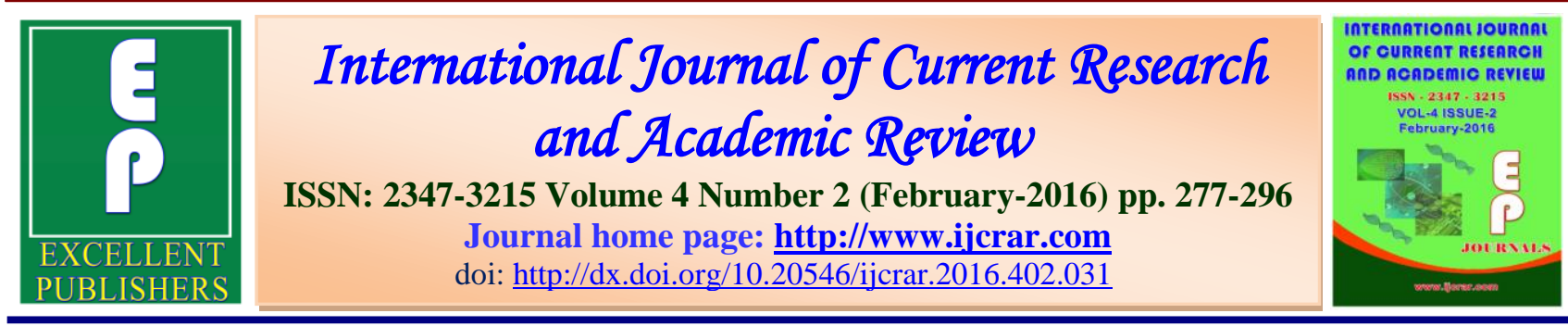

\title{
1, 2, 4-Triazole Scafolds: Recent Advances and Pharmacological Applications
}

\section{Anjali Thakur*, Puspraj S. Gupta, Parjanya kumar shukla, Amita verma and Prateek Pathak}

Department of Pharmaceutical chemistry, Faculty of Health Sciences, Sam Higginbottom Institute of Agriculture, Technology \& Sciences, Naini, Allahabad-211007, India

*Corresponding author

\begin{tabular}{l|l}
\multirow{2}{*}{$\begin{array}{l}\text { KEYWORDS } \\
\text { 1,2,4-triazoles, }\end{array}$} & A B S T R A C T \\
\cline { 2 - 2 } $\begin{array}{l}\text { Heterocycle } \\
\text { compounds, }\end{array}$ & $\begin{array}{l}\text { Antifungal, } \\
\text { Antimicrobial }\end{array}$ \\
$\begin{array}{l}\text { classes of compounds, possessing a wide spectrum of activities. The 1,2,4- } \\
\text { triazole nucleus is associated with diverse pharmacological activities such as } \\
\text { antibacterial, antifungal, hypoglycemic, antihypertensive, analgesic, anti- } \\
\text { inflammatory, anti-tumor, anti-viral, urease inhibition and many other } \\
\text { properties. Either as single heterocyclic derivatives or in fusion with the other } \\
\text { cycles, these heterocycle is emerging as the most explored center to obtain } \\
\text { clinically significant compounds. In present study we explore the method of } \\
\text { preparation, some recent advances and biological activities of 1,2,4-triazoles } \\
\text { which give an idea about this moiety as potent medicinal agent for new drug } \\
\text { discovery. }\end{array}$
\end{tabular}

\section{Introduction}

Now a day research for new drug discovery concentrated towards the development of safe therapeutic agents with clinical importance. In recent year heterocyclic compounds analogues and derivatives have attracted strong interest due to their useful biological and pharmacological properties. Azoles are important five membered heterocyclic rings containing at least one nitrogen atom like Isoxazole, Thiazole, Pyrazole and Triazole. 1,2,4 triazoles are one of the important moiety of medicinal agents which fulfill the requirements of new drug discovery. 1,2,4-Triazoles and their derivatives constitute an important class of organic compounds with diverse agricultural, industrial and biological activities including anti-microbial, sedative, anti-convulsant, anti-inflammatory and other properties, and consequently the synthesis of these heterocycles has received considerable attention in recent years. Some of the present day drugs such as Ribavirin (antiviral agent), Rizatriptan (antimigraine 
agent), Alprazolam (anxiolytic agent), Fluconazole and Itraconazole (antifungal agents) are the best examples for potent molecules possessing triazole nucleus.

The heteroaromatic triazole ring system is composed of five atoms, two carbon and 3 nitrogen, which can be arranged in two combinations to give 1,2,3-triazole(1) or to give 1,2,4-triazole(2)

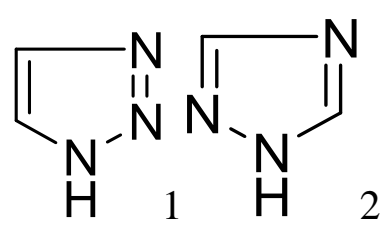

Although two $\mathrm{NH}$ and one $\mathrm{CH}_{2}$ tautomeric forms are possible for 1,2,4-triazole, this structure is best represent as a positively charged hydrogen associated with the resonance stabilized triazole anion.<smiles>c1nc[nH]n1</smiles><smiles>c1nnc[nH]1</smiles><smiles>C1=NCN=N1</smiles>

In other words 1,2,4-triazole refers to either one of a pair of isomeric chemical compounds with molecular formula $\mathrm{C} 2 \mathrm{H} 3 \mathrm{~N} 3$, having a five-membered ring of two carbon atoms and three nitrogen atoms. 1,2,4-triazoles are exist in two forms i.e. $1 H$ and $4 H$.<smiles>c1nc[nH]n1</smiles>

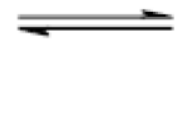

\section{triazoles}

Preparation of 1,2,4-triazoles via the Einhorn-Brunner cyclization Reaction

The Einhorn-Brunner reaction occurs between an alkyl hydrazine and an imide. This cyclization reaction is catalyzed by an organic acid, such as acetic acid[1].<smiles>[R]NN[NH2+][CH]C(C)C(C)=O</smiles>

Preparation of 1,2,4-triazoles via the Pellizzari cyclization Reaction

In the Pellizzari reaction, an acyl hydrazide is condensed with an amide at high temperature[2].

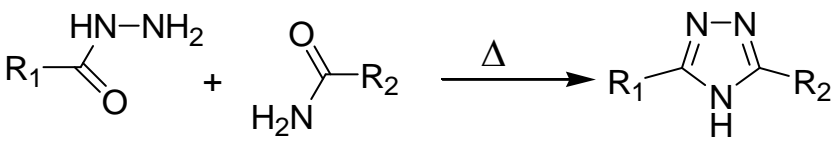

Prepration of 1,2,4-triazoles by 4acylthiosemicarbazide

5-aryl-1,2,4-triazole-3-thiones, were obtained by the reaction of 4acylthiosemicarbazide with $\mathrm{KOH} 10 \%$ under reflux, followed by the acidification with concentrated hydrochloric acid[3].

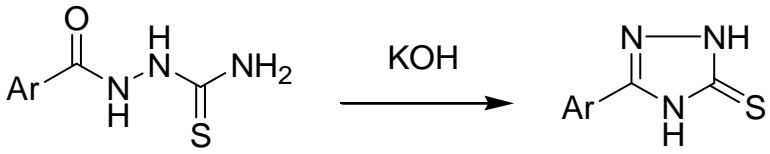

Prepration of 1,2,4-triazoles from Esters[4]

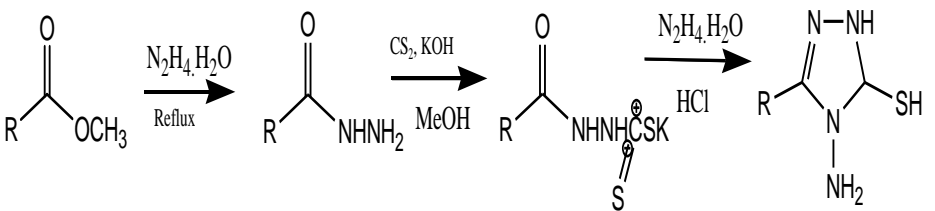

Prepration of 1,2,4-triazoles from Diacylhydrazide[5]<smiles>CC(=O)NNC(C)=O</smiles> 
Antifungal Activity and Antimicrobial Activity

Antifungal activity exhibited by many potent antifungal agents is attributed to the presence of triazole ring system. Major examples of triazole containing antifungal agents include

Fluconazole (3), Voriconazole (4) and Itraconazole (5).<smiles>OC(Cn1cncn1)(Cn1cncn1)c1ccc(I)cc1F</smiles><smiles>C[C@H](c1ncncc1F)[C@@](O)(Cn1cncn1)c1ccc([AlH2])cc1F</smiles><smiles>CCC(C)n1ncn(-c2ccc(N3CCN(c4ccc(OC[C@@H]5CO[C@@](Cn6cncn6)(c6ccc(Cl)cc6Cl)O5)cc4)CC3)cc2)c1=O</smiles>
5

Iraj Rahavi Ezabadi et al [6] synthesized a series of 10 new 5-[2-(substituted sulfamoyl)-4,5-dimethoxy-benzyl]-4aryl-striazole-3-thiones(6) and evaluated for in vitro antifungal and antibacterial activity. All compounds tested showed significant antifungal activity against all the micromycetes, compared to the commercial fungicide bifonazole.

Jianming $\mathrm{Xu}$ et al [7] designed and synthesized based a series of novel 1,2,4triazole derivatives with a 4-(4substitutedphenyl) piperazine side chain on the structure of lanosterol 14a-demethylase (CYP51). Their antifungal activities against eight human pathogenic fungi were evaluated in vitro and resulted that all tested compounds (7) were found to be more potent against Candida albicans than control drug fluconazole.<smiles>[R]NP([R])O[S+]([O-])c1cc(OC)c(OC)cc1Cc1n[nH]c(=S)n1Cc1ccc([R])cc1</smiles><smiles>[R]c1cc(N=CC)ccc1N1CCN(CC(O)(Cn2cncn2)c2ccc(F)cc2F)CC1</smiles>

Nuray Ulusoy Guzeldemirci et al [8] synthesized a series of 4-alkyl/aryl-2,4dihydro-5-((6-(4-bromophenyl)imidazo[2,1b]thiazol-3-yl)methyl)-3H-1,2,4-triazole-3thiones (8) starting from 6-(4bromophenyl)imidazo [2,1-b]thiazole-3acetic acid hydrazide. All compounds were tested for antibacterial and antifungal activities and resulted that these are potent antimicrobial agents.

Xiaoyun Chai et al [9] synthesized a series of 1-(1H-1,2,4-triazole-1-yl)-2-(2,4 difluorophenyl) -3-substituted benzylamino-2propanols (9) as analogs of fluconazole and evaluated as antifungal agents. Results of preliminary antifungal tests against eight 
human pathogenic fungi in vitro showed that all the title compounds exhibited excellent activities with broad spectrum.<smiles>O=c1[nH]nc(Cc2csc3nc(-c4ccc(Br)cc4)cn23)[nH]1</smiles><smiles>[R]NCC(O)(Cn1cncn1)c1ccc(F)cc1F</smiles>

Nisha Aggarwal et al [10] synthesized Novel nalidixic acid based 1,2,4-triazole (10) derivatives were synthesized and all these compounds were screened for antimicrobial activity against five bacteria and two pathogenic fungi. Most of these compounds showed better antimicrobial activity than the parent compound 4-amino5- mercapto-1,2,4-triazole.

Sumesh Eswaran et al [11] synthesized A new class of quinoline derivatives containing 1,2,4-triazole moiety (11) from derivatives of 4-hydroxy-8(trifluoromethyl)quinoline-3-carbohydrazide most of the compounds demonstrated very good antimicrobial activity, comparable to the first line standard drugs.

Seref Demirayak et al[12]synthesized some 3-arylamino-5-[2-(substituted imidazol-1-yl or benzimidazol-1-yl)ethyl]-1,2,4-triazole (12) derivatives by reacting 3-(substituted imidazol-1-yl)propionyl hydrazides, with $S$ methyl- $N \%$-arylisothiouronium iodide salts. Antimicrobial activities of the compounds were observed against Staphylococcus aureus, Micrococcus luteus, Escherichia coli B, Pseudomonas aeroginosa and the fungi Candida albicans and Candida glabrata by using the tube dilution technique.<smiles>[R]C=Nn1c(S)nnc1-c1c[nH]c2nc(C)ccc2c1=O</smiles><smiles>Cc1ccc2cc(-c3nncn3Cc3ccccc3)cnc2c1C(F)(F)F</smiles><smiles>[R]CCc1n[nH]c(Nc2ccc([R1])cc2)n1</smiles>

Yatin J. Mange et al [13] synthesized a series of new Schiff bases (13) by the condensationof $\mathrm{N}$-[(4-amino-5-sulfanyl-4H1,2,4-triazol-3-yl)methyl]-4-substitutedbenzamides all these compounds showed antimicrobial activity.

Nasser S. A. M. Khalil [14]studied that Glucosidation of some 4-amino- and 4arylideneamino-5-(pyridin-3-yl)-2,4dihydro-[1,2,4]-triazole-3-thiones (14) with 2,3,4,6-tetra-O-acetyl-a-D-glucopyranosyl bromide followed by chromatographic separation gave the corresponding $\mathrm{N}$ - and $\mathrm{S}$ b-D-glucosides. Antimicrobial screening of 14 selected compounds resulted in their activity against Aspergillus fumigatus, Penicillium italicum, Syncephalastrum racemosum, Candida albicans, Staphylococcus aureus, Pseudomonas aeruginosa, Bacillus subtilis, and Escherichia coli. 
Krzysztof Sztanke et al [15] synthesized 7(4-methylphenyl)-3-methylthio-5H-6,7dihydroimidazo[2,1-c][1,2,4]triazole (15) by the alkylation of the respective 7-(4methylphenyl)-2,5,6,7-tetrahydroimidazo [2,1-c] [1,2,4] triazol-3 (H)-thione with methyl iodide. Compoundwas found to be equipotent to chloramphenicol in vitro, whereas showed superior activity (MIC) to ampicillin.<smiles>[R]C=Nn1c(S)nnc1CNC(=O)c1ccc([R])cc1</smiles><smiles>CSc1nnc(C2CCCNC2)n1/N=C/[Ga]</smiles><smiles>CSc1nnc2n1CCN2c1ccc(C)cc1</smiles>

5

Qiu Qin He et al[16]synthesized novel triazole compounds (16) based on the active site of Aspergillus fumigatus lanosterol 14ademethylase (AF-CYP51). The results showed that all the target compounds exhibited excellent activities with broad spectrum; compounds showed comparable activities against $A$. fumigatus to the control drug itraconazole.

Xiaoyun Chai et al[17] synthesized a series of 1-(1H-1,2,4-triazol-1-yl)-2-(2,4-difluoro- phenyl)-3-[(4-substituted trifluoromethyl phenyl)-piperazin-1-yl]-propan-2-ols (17) and evaluated as antifungal agents. The MIC80 values indicate that the compounds showed higher antifungal activities against Candida albicans.<smiles>[R]COc1ccc(N2CCN(CC(O)(Cn3cncn3)c3ccc(F)cc3F)CC2)cc1</smiles><smiles>[R]C(=O)Nc1ccc(N2CCN(CC(O)(Cn3cncn3)c3ccc(F)cc3F)CC2)c(C(F)(F)F)c1</smiles>

Hacer Bayrak et al[18] synthesized 4amino-5-pyridin-4-yl-4H-1,2,4-triazole-3thiol (18). All newly synthesized compounds were screened for their antimicrobial activity. The antimicrobial activity study revealed that all the compounds screened showed good or moderate activity.

Haythem A. Saadeh et al [19] synthesized 1,2,4-triazole-3-thiol metronidazole derivatives (19) The antiparasitic activity of the compounds against Entamoeba histolytica and Giardia intestinalis was investigated. The antibacterial and antifungal activity of the compounds, assessed as minimal inhibitory concentration, was also investigated.

Zafer Asım Kaplancikl et al[20] synthesized new 1,2,4-triazole and 1,2,4-triazolo[3,4b] $[1,3,4]$ thiadiazine derivatives (20) were synthesized as novel antimicrobial agents. Their antimicrobial activities against Micrococcus luteus, Bacillus cereus, Proteus vulgaris, Salmonella typhimurium, Staphylococcus aureus, Escherichia coli, 
Candida albicans and Candida glabrata were investigated and significant activity was obtained.<smiles>CN1CCN(Cn2nc(-c3ccncc3)n(N=Cc3ccc(F)cc3)c2=S)CC1</smiles><smiles>[R]c1ccc(-c2nn3c(CC4CNc5ccccc54)nnc3nc2[N+](=O)[O-])cc1</smiles>

18

Kudari et al[21]synthesized certain Bis1,3,4-oxadiazoles, Bis- 1,3,4-thiadiazoles, Bis-1,2,4-triazoles (21), and Bis-N-amino 1,2,4- triazoles and screened them for antimicrobial activity.

Shigare et al[22]synthesized certain dihydro-pyridino triazoles (22) and thidiazoles and screened them for antimicrobial activity.<smiles>CC1NC(C)C(c2nnc(S)n2-c2ccccc2)C(c2ccccc2)C1c1nnc(S)n1-c1ccccc1</smiles><smiles>Sc1nnc(Nc2ccc(-c3nnc(S)n3-c3ccccc3)cc2)n1-c1ccccc1</smiles>

\section{Anticoulvensant Activity and Antipsycotic Activity}

The clinically useful derivatives of 1,2,3triazole includes Tazobactam (23) which is used in combination with $\beta$-lactam antibiotics as antibacterial and Rufinamide (24) an anticonvulsant.<smiles>C[C@]1(Cn2ccnn2)[C@H](C(=O)O)N2C(=O)C[C@H]2S1(=O)=O</smiles><smiles>NC(=O)c1cn(Cc2c(F)cccc2F)nn1</smiles>

Aniket et al[23] designed and synthesized the substituted N-(5-mercapto-3-pyridyl-3yl-4H-1,2,4-triazol-4-yl)- thiosemicarbazone from nicotinic acid and evaluated them for anticonvulsantactivity by Maximum Electroshock (MES) method and found that total recovery time and time for hind limb extension recovery for compound (25) was less than the standard (Phenytoin).

Jing Chen et al[24] synthesized 4-(4alkoxylphenyl)-3-ethyl-4H-1,2,4-triazoles from the condensation of Dimethoxy-N,Ndimethyl methanaminel, propionohydrazide and p-aminophenol Theanticonvulsant activities of the synthesized compound were evaluated by the maximal electroshock test and their neurotoxicity was evaluated by the rotarod neurotoxicity test and result showed 
that compound (26) produced significant antagonism activity against seizures induced by pentylenetetrazole, 3-mercaptopropionic acid, thiosemicarbazide and Isoniazid, suggested that the compound 3r might have effects on GABAergic neurotransmission and activate glutamate decarboxylase (GAD) or inhibit (GABA)-aoxoglutarateamino transferase (GABA-T) in the brain.

M. Shalini et al[25] synthesized some substituted diphenyl-1,2,4-triazole-3-ones by the condensation of substituted benzoyl chlorides and substituted phenyl semicarbazides. The anticonvulsant activity of these compound were screened by using four animal models of seizure which include, maximal electroshock seizure, subcutaneous pentylenetetrazole, subcutaneous strychnine, and subcutaneous picrotoxin induced seizure threshold tests. Neurotoxicity screening was done by Rotarod test to detect the motor deficit in mice., Behavioral depression was measured by evaluating the locomotor activity of the animal using actophotometer, CNS depression was studied by Porsolt's swim pool test. Results show that compound (27) exhibited anticonvulsant activity in all the four animal models of seizure.<smiles>S=C(NNc1cccc([123I])c1)Nn1c(S)nnc1-c1cccnc1</smiles><smiles></smiles><smiles>Cc1ccc(C)c(-n2c(-c3ccccc3)n[nH]c2=O)c1</smiles>

The triazole ring has been fused at 1,2position of 1,4-benzodiazepines to give Estrazolam (28)andTriazolam $\quad(\mathrm{R}=\mathrm{CH} 3$, $\mathrm{X}=\mathrm{Cl}, \mathrm{Y}=\mathrm{Cl})$ the potent hypnotic agents and Alprazolam ( $\mathrm{R}=\mathrm{CH} 3, \mathrm{X}=\mathrm{Cl}, \mathrm{Y}=\mathrm{H})$ (29) a potent antipsychotic agent.<smiles></smiles>

\section{Antitumor / Anticancer Activity}

K. Subrahmanya Bhat et al [26] synthesized a series of 3-(2,4-dichloro-5-fluorophenyl)6-(substituted phenyl)-1,2,4-triazolo[3,4-b]1,3,4-thiadiazines (30) . Among the compounds tested for their antitumor activity three compounds exhibited in vitro antitumor activity with moderate to excellent growth inhibition against a panel of sixty cancer cell lines of leukemia, nonsmall cell lung cancer, melanoma, ovarian cancer, prostate and breast cancer.

M. A. Kaldrikyan et al [27] synthesized a series of 3-benzofuryl-4-phenyl(allyl)-5mercapto-1,2,4-triazoles (31) by cyclization of the corresponding substituted thiosemicarbazides of benzofuran-2- 
carboxylic acid. The antitumor activity of the synthesized compounds was tested and found that some of them have potent antitumor activity.<smiles>[R7]n1c(COc2ccc(N([2H])C(=S)N[PH])cc2)n[nH]c1=S</smiles><smiles>[R]n1c(S)nnc1-c1cc2ccccc2o1</smiles>

Krzysztof Sztanke et al [28] synthesized derivatives of 3-Unsubstituted and 3substituted-7-aryl-5H-6,7-dihydroimidazo [2,1-c][1,2,4]triazoles (32). Compounds were evaluated for their cytotoxic activity against three cancer cell lines: human Caucasian colon adenocarcinoma cell line e LS180 (ECACC 87021202), human uterus carcinoma cell line e SiHa (ECACC $85060701)$ and human breast carcinoma cell line e T47D (ECACC 85102201). These showed potent antitumor activity.

Anelia Ts. Mavrova et al [29] synthesized novel derivatives of 4,5-substituted-1,2,4triazole-thiones (33) and evaluated for their cytotoxicity. The biological study indicated that compounds 4-ethyl-5-(4,5,6,7tetrahydro-1-benzothien-2-yl)-2,4-dihydro$3 \mathrm{H}-1,2,4$-triazole-3- thione and 4-amino-5(4,5,6,7-tetrahydro-1-benzothien-2-yl)-2, 4dihydro-3H-1,2,4-triazole-3-thione possessed high cytotoxicity in vitro against thymocytes.

Yaseen A. Al-Soud et al[30] synthesize 2[H-Benzotriazole-1-yl(methylene)]-6,7,8,9tetrahydro- $\quad 5 \mathrm{H}-[1,2,4]$ triazolo[1,5-a] azepine and other derivatives which are examined and showed that these derivatives has antitumor activity.
Datar, P. et al [31] synthesizedsome imidazolidinyl-triazolidin-5-thione derivatives (34). These derivatives were reported to possess weak antimicrobial activity against $S$. aureus, $S$. typhiand $C$. albicans. The anticancer study indicates that these compounds possess $100 \%$ cytotoxicityagainst Dalton's lymphoma cell lines and Ehrlich ascites carcinoma cell lines.

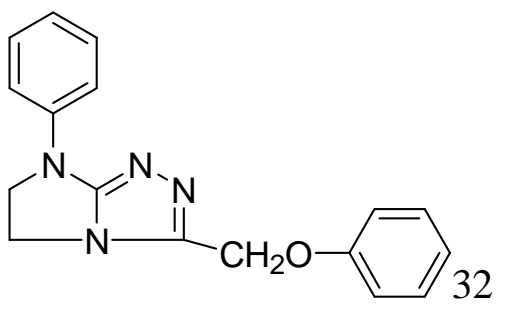<smiles>[Y3]CNc1nnc(-c2cc([R])c([R])s2)s1</smiles><smiles>[R]n1c(O)nn(C2=NC(=O)C(c3ccccc3)(c3ccccc3)N2)c1=S</smiles>

\section{Anti-inflammatory Activity}

Birsen Tozkoparan et al[32] prepared a series of 5-aryl-3-alkylthio-1,2,4-triazoles (35) and corresponding sulfones, these compounds showing better significant analgesic-antiinflammatory activity with minimum ulcerogenic risk.

Latifeh Navidpour et al[33]designed and synthesized a new type of 4,5-diaryl-4H1,2,4-triazole, possessing $\mathrm{C}$-3 thio and alkylthio ( $\mathrm{SH}, \mathrm{SMe}$ or $\mathrm{SEt}$ ) substituents (36), these compounds were evaluated as selective cyclooxygenase-2 (COX-2) inhibitors with in vivo anti-inflammatory activity. 
Ashraf M. Abdel-Megeed et al [34] synthesized 1-acylated-5-amino-1,2,4triazole-3-acetates and their derivatives (37) which showed higher anti-inflammatory activity than the corresponding 5-acylamino derivatives in carageenan-induced rat paw edema test with low gastric ulcerogenicity compared with indomethacin.<smiles>[Y]C1N=C([R5]([R])([H])[H])n2[nH]n21</smiles><smiles>[X]c1ccc(-n2c(S)nnc2-c2ccc(S(C)(=O)=O)cc2)cc1</smiles><smiles>[X]c1ccc(C(=O)Nc2nc(CC(=O)OCC)n[nH]2)cc1</smiles>

Chetan M. Bhalgat et al [35] carried out the synthesis of novel dihydropyrimidine carbonitrile, its dimethylated adduct, and hydrazine derivative of and its triazole fused derivatives (38). Further the novel derivatives were investigated for their in vitro antioxidant and anti-inflammatory activity. The results revealed that some of the tested compounds showed potent antioxidant and anti-inflammatory activity.
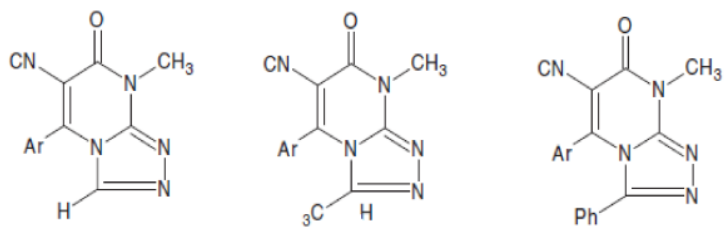

38

Umut et al [36] reported a series of 1acylthiosemicarbazides, 1,2,4-triazole5(4H)-thiones, 1,3,4-thiadiazoles and hydrazones containing 5-methyl-2benzoxazolinones from the reaction of 5methyl-2-hydroxyaniline and urea and evaluated anti-inflammatory, analgesic activity. The newly synthesized compounds were tested for their analgesic and antiinflammatory activities. tested compounds (39) possessed considerably high amount of analgesic activity and high antiinflammatory activity.

Peter, C. et al[37] reported antiinflammatory activity of 1-acyl-3-psubstituted-phenyl-5-

alkyl-triazole (40) . Modification of the acyl group, p-substituted phenyl and alkyl group led to the selection of the most active member of the series, 1-acetyl-3-(pchlorophenyl)-5-methyl-1,2,4-triazole, for further evaluation as a novel non-acidic antiinflammatory agent.

Stenberg V. et al[38] prepared and evaluate the anti-inflammatory activity of [(4-phenyl5-aryl-4H-1,2, 4-triazole-3-yl) -thio]-acetic acid derivatives (41). The hydroxyl substituted derivatives compounds were effective as in vitro scavengers of peroxide but were not effective as in vivo antiinflammatory agents.<smiles>Cc1ccc2oc(=O)n(CC(=O)NN)c2c1</smiles><smiles>CC=COC1CCCCC1(C)OC(C)=O</smiles><smiles>[R]OC(=O)CSc1nnc([Al])n1-c1ccccc1</smiles>

\section{Anti tubercular Activity}

Navin B. Patel et al [39] synthesized a series of 3-(3-pyridyl)-5-(4-methylphenyl)-4-(N- 
substituted-1,3-benzothiazol-2-amino)-4H1,2,4- Triazole (42) and also observed that these are promising antimicrobials have proved to be better antituberculars. Some Compound showed better antitubercular activity compared to rifampicin.

Ilkay Kuc,ukguzel et al[40] synthesized a series of novel 5-[(4-aminophenoxy)methyl] -4-alkyl/aryl-2,4-dihydro-3H-1,2,4triazole-3-thiones and several related thioureas, N-alkyl/aryl-N0-\{4-[(4-alkyl/aryl5-thioxo- 4,5-dihydro-1H-1,2,4-triazol-3yl)methoxy]phenyl thioureas (43) and evaluated for antiviral potency. compounds were evaluated in vitro against HIV-1 (IIIB) and HIV-2 (ROD) strains in MT-4 cells, as well as other selected viruses such as HSV1, HSV-2, Coxsackie virus B4, Sindbis virus and Varicella-zoster virus using HeLa, Vero, HEL and E6SM cell cultures, and antituberculosis activity against Mycobacterium tuberculosis H37Rv. Some of them were found very potent.

Alagarsamy, V. et al[41] synthesized some novel 1,4-disubstituted-1,2,4-triazolo [4,3a]- quinazolin-5(4H)-ones (44) and screened for anti HIV and antimicrobial activity. Their study indicates that the synthesized compounds do not exhibit significant antiHIV activity while the synthesized derivatives possess good activity against $M$. tuberculosis, C. albicans and A. niger.<smiles>[R]c1cccc2c1SC(Nn1c(-c3ccc(C)cc3)nnc1-c1cccnc1)N2</smiles>

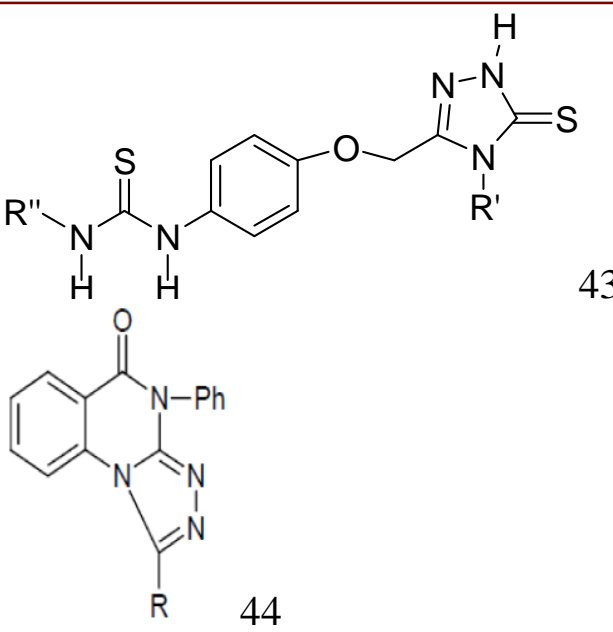

Shingare et al[42]synthesized certain 1,4benzothiazinyl thiosemicarbazides, triazoles (45), oxadiazoles, and thiadiazoles and screened them for anti-tubercular activity.

S.D. Joshi et al[43] synthesized a novel series of some derived 5-substituted-4amino-1,2,4-triazolin-3-thione

Compounds were evaluated for their preliminary in vitro antibacterial activity against some Gram-positive and Gramnegative bacteria and compounds were screened for antitubercular activity against Mycobacterium tuberculosis H37Rv strain by broth dilution assay method. Some compounds showed very good antibacterial and antitubercular activities.

Udupi et al[44]carried out their studies on antitubercular agents. They synthesized 4pyridoyl-3-substitued-1, 2,4-triazolo (3,4-b) $(1,3,4)$-thiadiazolidines (47), and exhibiting significant anti-tubercular activity. They also reported the anti-inflammatory activity for some of the compounds synthesized.

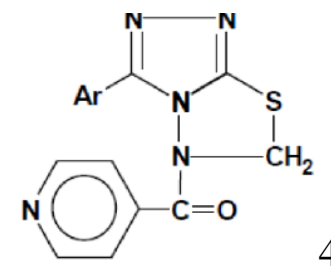




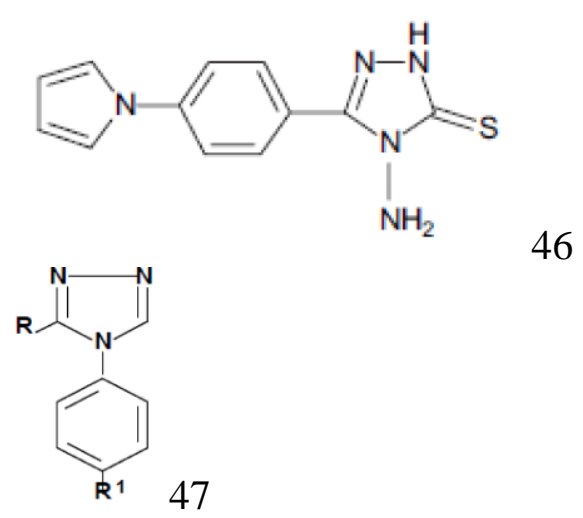

Udupi et al[45]carried out the synthesis and biological activity of 3-pyridyl-4-[Nsubstituted phenyl carboxamido]-5mercapto-1,2,4- triazoles (48) and screened them for anti-bacterial, anti-fungal and antitubercular activity.

Nuray Ulusoy $\mathrm{Gu}$ zeldemirci et al[46] synthesized a series of 4-alkyl/aryl-2,4dihydro-5-((6-(4-bromophenyl)imidazo[2,1b]thiazol-3-yl)methyl)-3H-1,2,4- triazole-3thiones (49) . Compounds were also evaluated for antituberculosis activity against Mycobacterium tuberculosis H37Rv (ATCC 27294). The preliminary results revealed that some of the compounds exhibited promising antimicrobial activities.

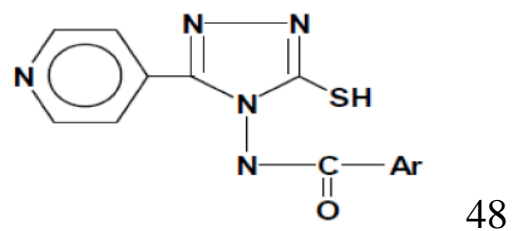

49

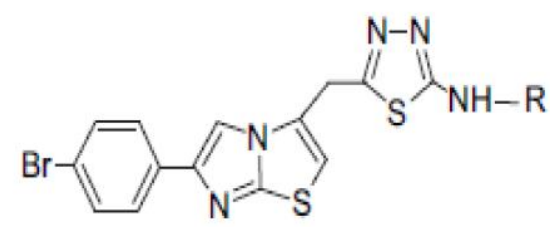

triazole-3-thiones (50) and 2,5-disubstituted1,3,4-thiadiazoles by dehydrative cyclization of hydrazinecarbothioamide derivatives, compounds were screened for their antioxidant and urease inhibition activities. 4-(2,3-dimethylphenyl)-5-phenyl-2,4dihydro-3H-1,2,4-triazole-3-thione exhibited potent urease inhibitory activities.

Monazza et al[48] reported 5-aryl-4-(1phenylpropyl)-2H-1,2,4-triazole-3(4H)thiones from aryl carboxylic acids as a potent inhibitor of Jack bean urease. Compound (51) was found to be more potent than the standard, with the IC50 values of $7.8 \pm 0.2$ compared to standard thiourea with IC50 $=21.0 \pm 0.1$ $\mu \mathrm{M})$.

Mahmood-ul-Hassan Khan et al[49] synthesized a series of 4-amino-5aryl-3H-1,2,4-triazole-3-thiones (52) by reaction of aryl hydrazideswith CS2 and hydrazine hydrate and their urease inhibition activity was evaluated usingjack bean urease. All but one of the synthesized compoundswere active, and two of them were found to be more potentthan the standard, with 50\% inhibition concentration (IC50)values of $17.5 \pm 0.52$ and $4.3 \pm 0.169$ $1 \mathrm{M}$, respectively(standard IC50 $=21.0 \pm$ $0.11 \mathrm{lM})$. Tentative statementsregarding the role of different functional groups in bindingto the enzyme active site are also presented.

\section{Urease Inhibition}

Imtiaz Khan et al[47] synthesized new series of 4,5-disubstituted-2,4-dihydro-3H-1,2,4- 
<smiles>CCC(c1ccccc1)n1c(-c2ccccc2Br)n[nH]c1=S</smiles>

\section{Antioxidant Activity}

Rohini et al [50] synthesized bis-triazole derivatives, 5, 5/-methylene bis [4substituted phenyl/alkyl -4H-1, 2, 4-triazole3-thiol] screened for their antioxidant by DPPH method and anti-inflammatory activities by carrageenin induced paw oedema method. One of the compound (53) was found to have potent antioxidant and anti-inflammatory activity.

Yuksek, H. et al[51] some 4-benzylidenamino-4,5-dihydro-1H-1,2,4-triazole-5one derivatives (54) and investigated for antioxidant property. Their study indicatesthat the compounds with phenyl substitute group possess good antioxidant property.<smiles>Cc1ccc(-n2c(S)nnc2Cc2nnc(S)n2-c2ccc(C)cc2)cc1</smiles><smiles>[R]c1n[nH]c(=O)n1N=Cc1ccc(O)c(O)c1</smiles>

\section{Plant Growth Activity}

Xue Qin et al[52]presented a series of N-(5((1H-1,2,4-triazol-1-yl)methyl)-4-tertbutyl thiazol- 2-yl)-4-carboxamide derivatives (55) and evaluated plant-growth regulatory activity by using cucumber cotyledon rhizogenesis method, The studies suggested that the presence of fluorine atom at position $2,3,4$ of phenyl ring are crucial for exhibited plant-growth regulatory activities and the substitution with chlorine atom at both 2- position and 4-position of benzene ring caused a decrease of the activity while the presence of a strong electronwithdrawing group such as nitro-group led to decrease in activity.compound having fluorine atom at 4 th position connected to the phenyl ring produced exellent plantgrowth regulatory activity.

Jianbing Liu et al[53] synthesized some new 1H-1,2,4-triazole derivatives (56) containing ferrocenyl moiety in various yields by the condensation of ferrocenecarboxaldehyde with 1-(1H-1,2,4 triazol-1-yl)-3-aryl-2-one in toluene. Their results of bioassay showed that some title compounds exhibited some degree of antifungal and plant growth regulatory activities.<smiles>CC(C)(C)c1nc(NC(=O)c2ccc(F)cc2)sc1Cn1cncn1</smiles>

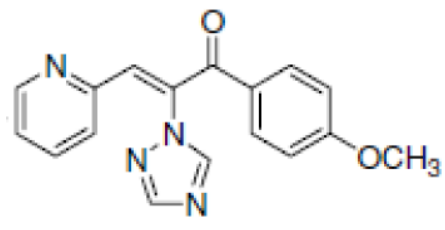

Antiestrogens

Some derivatives of $1 H-1,2,4-$ triazole are also found to be useful as potent antiestrogens, major examples of which are Anastrozole (57), vorozole (58) and letrozole (59). 
<smiles>CC(C)(C)c1cc(Cn2cncn2)cc(C(C)(C)C)c1</smiles>

57<smiles>Cn1nnc2ccc(C(c3ccc(Cl)cc3)n3cncn3)cc21</smiles>

\section{8}<smiles>N#Cc1ccc(C(c2ccc(C#N)cc2)n2cncn2)cc1</smiles>

59

\section{Other Biological Activites of Triazoles}

Ribavirin (60) an antiviral agent, Israpafant (61) an antiasthmatic, Lotrifen (62) an Abortifacient.<smiles>NC(=O)c1ncn(C2OC(CO)C(O)C2O)n1</smiles><smiles>Cc1ccc(CSc2cc3c(s2)-n2cnnc2C(C)N=C3c2ccccc2Cl)cc1</smiles><smiles>Clc1ccc(-c2nc3n(n2)CCc2ccccc2-3)cc1</smiles>

John M. Kane et al[54]synthesized a series of 5-aryl-2,4-dihydro-3H-1,2,4-triazol-3thiones(63) and evaluated their antidepressant activity. Members of this series were found to possess potentantide pressant property.

Xin Yong et al [55] prepare a series of 4Amino-5-furyl-2-yl-4H-1, 2, 4-triazole-3thiolderivatives and assayed for their Endothelin (ET) Receptor Antagonists by using the cell culture solution of the rat heart ventricle muscle membranes. Compound (64) represented a new leading compound of ET receptor antagonist which exhibited high inhibition of $71.93 \%$.<smiles>[R2]n1nc([Al])n([R2])c1=S</smiles><smiles>O=[N+]([O-])c1occc1/C=N/n1c(S)nnc1-c1ccco1</smiles>

Sen et al[56]synthesized 2-o-chlorophenyl5-oxo-5,6 dihydro- $4 \mathrm{H}$ thiazolo [2,3-b] 1,3,4-triazoles (65) and screened them for anti-filarial activity.

Mohan et al[57]synthesized certain thiazolo [3,2-b]-s-triazoles and isomeric thiazolo[2,3c]-s-triazoles (66) and screened them for anti-microbial and diuretic activity.

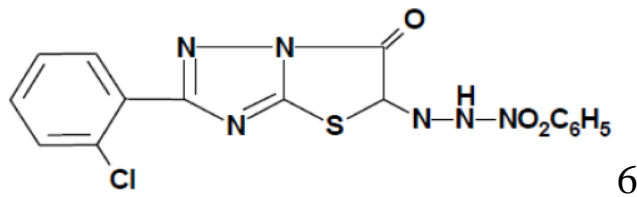




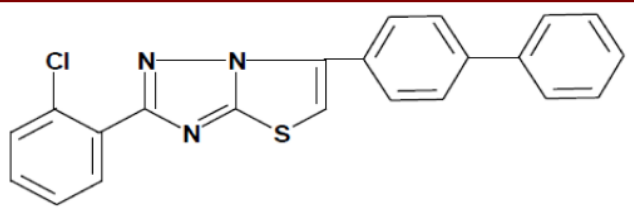

66

Chande et al [58] synthesized organophosphorus compounds containing substituted s-triazole and fused ring heterocycles (67) screened them for insecticidal activity.

Kudari et al[59]carried out the synthesis of 1,8-Bis (4-amino-5-mercapto-1,2,4-triazol3-yl) octanes and the derivatives (68a, 68b) . Some of the bis-triazoles have shown antiHIV, anti-cancer particularly prostrate cancer and anti-fertility activity.

Dae-Kee Kim et al[60]synthesized, and performed biological evaluation of novel 2pyridinyl- $[1,2,4]$ triazoles (69) as inhibitors of transforming growth factorb1 type 1 receptor.<smiles>COP(=S)(OC)SCc1nnc2sc(=S)[nH]n12</smiles>

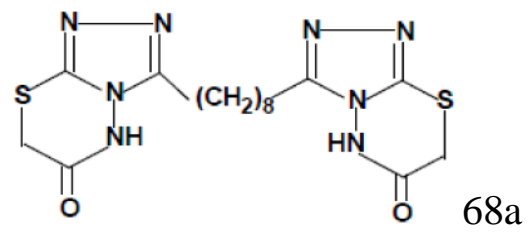<smiles>NNc1nnc(CCc2nnc(NN)n2N)n1N</smiles><smiles>[R2]c1cccc(-n2nc(-c3ccc(C(N)=O)cc3)nc2[R])n1</smiles>

Tahmineh Akbarzadeh et al[61] synthesized a series of new 5-substituted analogues of 4H-3-(2-phenoxy)phenyl-1,2,4-triazole (70) and its chlorinated derivatives. Conformational analysis and superimposition of energy minima conformers of the compounds on estazolam, a known benzodiazepine receptor agonist, revealed that the main proposed benzodiazepine pharmacophores were well matched. Rotarod and pentylenetetrazoleinduced lethal convulsion tests showed that the introduction of an amino group in position 5 of 1,2,4-triazole ring especially in chlorinated derivatives had the best effect which was comparable with diazepam.

Mahmoud Balba et al[62] investigated in vivo and in vitro effects of 4,5-Diphenyl1,2,4-triazole-3-thiol (71) and 5-(2Hydroxyphenyl)-4-phenyl-1,2,4-triazole-3thiol (72) on a-glucosidase and a-amylase. 4,5-Diphenyl-1,2,4-triazole-3-thione showed a reversible inhibition of the competitive and non-competitive types, with $\mathrm{Ki}$ value of 10_5 M magnitude, for a-glucosidase and aamylase. On the other hand, 5-(ohydroxyphenyl)-4-phenyl-1,2,4-triazole-3thione did not display an inhibitory effect towards a-amylase but showed a potent inhibition of the competitive type for hepatic a-glucosidase with 10_5 M magnitude of $\mathrm{Ki}$ value.<smiles>[X]c1ccc(-c2nnc(S(=O)(=O)O)[nH]2)c(Oc2ccccc2[X])c1</smiles> 
<smiles>Sc1nnc(-c2ccccc2)n1-c1ccccc1</smiles><smiles>Oc1ccccc1-c1nnc(S)n1-c1ccccc1</smiles>

Agata Siwek et al[63] studied and investigated that by the reaction of 2methyl-furan-3-carboxylic acid hydrazide with isothiocyanates, 1-[(2-methyl-furan-3yl)carbonyl]-4-substituted

thiosemicarbazides were obtained. Further cyclization with $2 \% \mathrm{NaOH}$ led to the formation of 3-(2-methyl-furan-3-yl)-4substituted- $\quad \Delta 2-1,2,4$-triazoline-5-thiones (73). The pharmacological effects on the central nervous system in mice were investigated. Strong antinociceptive properties of the investigated derivatives were observed in a wide range of doses.

Anees A. Siddiqui et al [64] synthesized a number of 6-(substituted phenyl)-2-(4substituted phenyl-5-thioxo-4,5-dihydro-1H1,2,4-triazol-3- yl)-4,5-dihydropyridazin$3(2 \mathrm{H})$-one derivatives by a sequence of reactions starting from respective aryl hydrocarbons. The final compounds (74) were evaluated for antihypertensive activities by non-invasive method using Tail Cuff method. The compounds showed appreciable antihypertensive activity comparable with that of standard hydralazine and propranolol.

Xiaohu Ouyang et al[65] studied a novel triazole-containing chemical series (75) was shown to inhibit tubulin polymerization and cause cell cycle arrest inA431 cancer cells with EC50 values in the single digit nanomolar range. Binding experiments demonstrated that representative active compounds of this class compete with colchicine for its binding site on tubulin<smiles>[R]n1c(-c2ccoc2C)n[nH]c1=S</smiles>

73

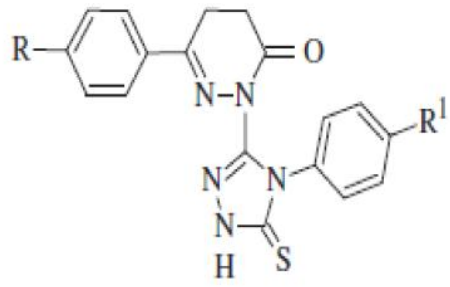<smiles>COc1cccc(Nc2nnc(-c3cccnc3Nc3cc(OC)cc(OC)c3)[nH]2)c1</smiles>

74

\section{Conclusion}

After a detail study of recent research and advances of 1,2,4-triazoles and its derivatives we can say that this heterocyclic azole moietycan be consider as the very important and potent moiety in new drug discovery. 1,2,4-triazoles can be consider with different biological activities such as antimicrobial, antipshycotic, antifungal, antitubercular, antiviral, anticancer, urease inhibitor, antihypertensive, plant growth regulator, abortifacient, antinoceceptive, anti-inflammatory, anticoulvensent etc.

\section{References}

1. Einhorn A., Bischkopff E., SzelinskiB., SchuppG., MauermayerT., Annln;Triazoles and tetrazoles: Prime ligands to generate remarkable 
coordination materials Coordination Chemistry; ReviewsChem. 343 (1905) 207-305.

2. PellizzariG., Gazz;Formation of substituted 1,2,4-triazoles by the condensation of amides and acyl hydrazines;Chim. Ital. 41 (1911) 20;

3. Tozkoparan B.,Peli E.,Ilada E.Y.and Ertan M;Preparation of 5-aryl-3alkylthio-1,2,4-triazoles and corresponding sulfones with antiinflammatory-analgesic activity; Bioorganic \& Medicinal Chemistry 15 (2007) 1808-1814

4. Kumar H;Synthesis and Characterization of 1,2,4-triazole and theirdiazotized compound as Bio-active agents;J. Chem. \& Cheml. Sci. Vol.1 (1), 1-19 (2010)

5. Anisworth C. and Jones R.G;Synthesis of 1H-1,2,4-Triazole;J Am. Chem. Soc. 1955, 77, 621 .

6. Ezabadi I.R.,Camoutsis C.,Zoumpoulakis P., Geronikaki A., Sokovic M.,Ilija J. G.and Ciric A; Sulfonamide-1,2,4triazole derivatives as antifungaland antibacterial agents: Synthesis, biological evaluation, lipophilicity, and conformational studies;Bioorganic \& Medicinal Chemistry 16 (2008) 1150-1161

7. Xu J., Cao Y., Zhang J., Yu S., Zou Y., Chai X., Wu Q., Zhang D., Jiang Y., Sun Q; Design, synthesis and antifungal activities of novel 1,2,4triazole derivatives; European Journal of Medicinal Chemistry 46 (2011) $3142 \mathrm{e} 3148$

8. Guzeldemirci N., Kucukbasmac O; Synthesis and antimicrobial activity evaluation of new 1,2,4-triazoles and 1,3,4-thiadiazoles bearing imidazo[2,1-b] thiazole moiety; European Journal of Medicinal Chemistry 45 (2010) 63-68
9. Chai X., Xu J., Cao Y., Zhang J., Yu S., Zou Y., Wu Q., Zhang D., Jiang Y., Sun Q;Design, synthesis, and biological evaluation of novel 1- $(1 \mathrm{H}-$ 1,2,4-triazole-1-yl)-2-(2,4difluorophenyl)-3-substituted benzylamino-2-propanols; Bioorganic \& Medicinal Chemistry Letters 19 (2009) 1811-1814

10. Aggarwal N., Kumar R., Dureja P., KhuranaJ.M;Synthesis, antimicrobial evaluation and qsar analysis of novel nalidixic acid based 1,2,4-triazole derivatives; European Journal of Medicinal Chemistry (2011), doi: 10.1016/j.ejmech.2011.06.009

11. Eswaran S,, Vasudeva, Adhikari N., Shetty S; Synthesis and antimicrobial activities of novel quinoline derivatives carrying 1,2,4-triazole moiety;European Journal of Medicinal Chemistry 44 (2009) 4637-4647

12. Demirayaka S., Benklia K., Guvenb K; Synthesis and antimicrobial activities of some 3-arylamino-5-[2(substituted-1-imidazolyl)ethyl]-1,2,4triazole derivatives; Eur. J. Med. Chem. 35 (2000) 1037-1040

13. Mange Y.J., Isloor A.M., Malladi S., Isloor S; Synthesis and antimicrobial activities of some novel 1,2,4-triazole derivatives; Arabian Journal of Chemistry (2011), doi:10.1016/j.arabjc.2011.01.033

14. Nasser S. A., KhalilM; Efficient synthesis, structure, and antimicrobial activity of some novel $\mathrm{N}$ - and S-b-Dglucosides of 5-pyridin-3-yl-1,2,4triazoles; Carbohydrate Research 341 (2006) 2187-2199

15. Sztanke K., Pasternak K.,Wo jtowicz A.S.,TruchlinskaJ. and Jozwiak $\mathrm{K}$;Synthesis, determination of the lipophilicity, anticancer andantimicrobial properties of some fused 1,2,4-triazole derivatives; 
Bioorganic \& Medicinal Chemistry 14 (2006) 3635-3642

16. He Q.Q., Liu C.M., Li K., Cao Y.B; Design, synthesis of novel antifungal triazole derivatives with high activities against Aspergillus fumigates; Chinese Chemical Letters 18 (2007) 421-423

17. Chai X., Zhang J., Cao Y., Zou Y., Qiuye W., Zhang D., Jiang Y.,Sun Q; Design, synthesis, and biological evaluation of novel 1-(1H-1,2,4triazole-1-yl)-2-(2,4-difluorophenyl)3-substituted benzylamino-2propanols; European Journal of Medicinal Chemistry 46 (2011)

18. Bayrak H., Demirbas A., Demirbas N., Karaoglu S.A; Synthesis of some new 1,2,4-triazoles starting from isonicotinic acid hydrazide and evaluation of their antimicrobial activities; European Journal of Medicinal Chemistry 44 (2009) 43624366

19. Saadeh H.A., Mosleh I.M., Al-Bakri A.G., Mubarak M.S; Synthesis and antimicrobial activity of new 1,2,4triazole-3-thiol metronidazole derivatives; Monatsh Chem (2010) 141:471-478

20. Kaplanciklı Z.A., Turan-Zitouni G., Ozdemir A., Revial G; New triazole and triazolothiadiazine derivatives as possible antimicrobial agents; European Journal of Medicinal Chemistry 43 (2008) 155e159

21. Kudari S.M., Mathapti V.V., Lagali K.V; Synthesis and antimicrobial activity of some heterocycles; Indian J Heterocyclic Chem 1996; 5: 203.

22. Shingare M.S., Tore S.N., Mane D.V., Bhawasar S.B., Garjare A.S., Shind D.B; Synthesis ofdihydro-pyridino triazoles; Indian J Heterocyclic Chem 1995; 5: 161.
23. Kshirsagar A., Toraskar M., Kulkarni V.M., Dhanashirea S., Kadam V; Microwave Assisted Synthesis of Potential Anti-infective and Anticonvulsant Thiosemicarbazones; InternationalJournal of Chem Tech., 2009, 1(3), 696.

24. Chen J., Sun X.Y., Chai K.Y., Lee J.S., Song M.S., Quan Z.S; Synthesis and anticonvulsant evaluation of 3substituted-4-(4-hexyloxyphenyl)-4H1,2,4-triazoles;Bioorganic \& Medicinal Chemistry., 2007, 15, 6775.

25. Shalini M., Yogeeswari P., Sriram D., Stables J.P; Cyclization of the semicarbazone template of aryl semicarbazones: synthesis and anticonvulsant activity of 4,5diphenyl-2H-1,2,4-triazol-3(4H)-one; Biomedicine \& pharmacotherapy., 2009, 63,187.

26. Bhat K.S., Poojary B., Prasad D.J., Naik P., Holla B.S;Synthesis and antitumor activity studies of some new fused 1,2,4-triazole derivatives carrying 2,4dichloro-5-fluorophenyl moiety; European Journal of Medicinal Chemistry 44 (2009) 5066-5070

27. Kaldrikyan M.A., Grigoryan L.A., Melik-Ogandzhanyan R.G., Arsenyan F.G;Synthesis and Antitumor Activity of Some Benzofuryl-substituted 1,2,4triazoles; Pharmaceutical Chemistry Journal Vol. 43, No. 5, 2009

28. Sztanke K., Tuzimski T., Rzymowska J., Pasternak K., Kandefer-Szerszen M; Synthesis, determination of the lipophilicity, anticancer and antimicrobial properties of some fused 1,2,4-triazole derivatives; European Journal of Medicinal Chemistry 43 (2008) 404e419

29. Mavrova A.T., Wesselinova D., Tsenov Y.A., Denkova P; Synthesis, cytotoxicity and effects of some 1,2,4triazole and 1,3,4-thiadiazole 
derivatives on immunocompetent cells; European Journal of Medicinal Chemistry 44 (2009) 63e69

30. Al-Soud Y.A., Al-Masoudib N.A., ElRahman A, Ferwanah;Synthesis and Properties of New Substituted 1,2,4Triazoles:Potential Antitumor Agents;Bioorganic \& Medicinal Chemistry 11 (2003) 1701-1708

31. Datar P.A., Shirodkar P.Y., Panikkar K.R;Synthesis of new 4-aryl/alkyl-1(5ф,5ф-diphenyl-4ф-oxo-1H-4,5dihydro-imidazolidin-2-yl)-3-hydro$\mathrm{xy}$-1,2,4-triazolidine-5-thiones as potential anti-cancer agents;Ind. J. Chem. Sect-B, 2003, 42B(3), 690.

32. Tozkoparan,B., Kupeli E.,Yesilada E., Ertan M;Preparation of 5-aryl-3alkylthio-1,2,4-triazoles and corresponding sulfones with antiinflammatory-analgesic activity; Bioorganic \& Medicinal Chemistry 15 (2007) 1808-1814

33. Navidpour L.,Shafaroodi H.,Abdi K.,Amini M.,Ghahremani M.H.,Dehpour A.R.and Shafiee A;Design, synthesis, and biological evaluation of substituted 3-alkylthio4,5-diaryl-4H-1,2,4-triazoles as selective COX-2 inhibitors;Bioorganic \& Medicinal Chemistry 14 (2006) 2507-2517

34. Abdel-Megeed A.M., Abdel-Rahman, Alkaramany $\quad$ S, El-Gendy M.A;Design, synthesis and molecular modeling study of acylated 1,2,4triazole-3-acetates with potential antiinflammatory activity;European Journal of Medicinal Chemistry 44 (2009) 117e123

35. Bhalgat C.M., Ali M.I., Ramesh B., Ramu G;Novel pyrimidine and its triazole fused derivatives:Synthesis and investigation of antioxidant and anti-inflammatory activity;Arabian
Journal of Chemistry (2011), doi:10.1016/j.arabjc.2010.12.021

36. Goksen U.S., Kelekc N.G., Goktas, Koysal Y., Kılıc E., Isık S., Aktay G., Ozalp M;

1-Acylthiosemicarbazides, 1,2,4-triazole5(4H)-thiones, 1,3,4-thiadiazoles and hydrazones containing 5-methyl-2benzoxazolinones: Synthesis, analgesic-anti-inflammatory and antimicrobial activities;Bioorganic \& Medicinal Chemistry, 2007, 15, 5738.

37. Wade P.C., Vogt B.R., Kissick T.P., Simpkins L.M, Palmer D.M., Millonig R.C; 1-Acyltriazoles as antiinflammatory agents;J. Med. Chem. 1982, 25, 331.

38. Maxwell J.R., Wasdahl D.A., Wolfson A.C., Stenberg V.I; Synthesis of 5aryl-2H-tetrazoles, 5-aryl-2Htetrazole-2-acetic acids, and [(4phenyl-5-aryl-4H-1,2,4-triazol-3-

yl)thio]acetic acids as possible superoxide scavengers and antiinflammatory agents;J. Med. Chem. 1984,27, 1565.

39. Patel N.B., Khan I.H., Rajani S.D; Pharmacological evaluation and characterizations of newly synthesized 1,2,4-triazoles; European Journal of Medicinal Chemistry $45 \quad$ (2010) 4293 e4299

40. Kucukguzel I., Tatar E., Kucukguzel S.G., Rollas S., Clercq E.D;Synthesis of some novel thiourea derivatives obtained from 5-[(4aminophenoxy)methyl]-4-alkyl/aryl2,4-dihydro-3H-1,2,4-triazole-3thiones and evaluation as antiviral/anti-HIV and antituberculosis agents;European Journal of Medicinal Chemistry 43 (2008) 381e392

41.Alagarsamy V., Giridhar R., Yadav M.R., Revathi R., Ruckmani K., Clercq E.D;AntiHIV, antibacterial and 
antifungal activities of some novel 1,4-disubstituted-1,2,4-triazolo[4,3-a] quinazolin-5(4 h )-ones; Ind. J. Pharm. Sci. 2006, 68(4), 532.

42. Shingare M.S., Chaudari B.R., Shinde D.B; Synthesis of1,4-benzothiazinyl thiosemicarbazides, triazoles, oxadiazoles, and thiadiazoles; Indian $\mathbf{J}$ Heterocyclic Chem 1995; 4: 187.

43. Joshi S.D., Vagdevi H.M., Vaidya V .P., Gadaginamath G.S; Synthesis of new 4-pyrrol-1-yl benzoic acid hydrazide analogs and some derived oxadiazole, triazole and pyrrole ring systems: A novel class of potential antibacterial and antitubercular agents; European Journal of Medicinal Chemistry 43 (2008) 1989e1996

44. Udupi R.H., Purushottamachar P., Bhat A.R; Synthesis of 4-pyridoyl-3substitued-1, 2,4-triazolo (3,4-b) $(1,3,4)$-thiadiazolidines exhibiting significant anti-tubercular activity; Indian J Heterocyclic Chem 2000; 9: 287.

45. Udupi R.H., Purushottamachar P; Synthesis and antimicrobial activity of some triazoles; Indian J Heterocyclic Chem 2000; 9: 189.

46. Guzeldemirci N.U., Kuchkbasmac $\mathrm{O}$;Synthesis and antimicrobial activity evaluation of new 1,2,4-triazoles and 1,3,4-thiadiazoles bearing imidazo[2,1-b]thiazole moiety; European Journal of Medicinal Chemistry 45 (2010) 63-68

47. Khan I., Ali S., Hameed S., Rama N.H., Hussain M.T.,Wadood A., Uddin R., Haq Z.U., Khan A., Choudhary M.I;Synthesis, antioxidant activities and urease inhibition of some new 1,2,4-triazoleand 1,3,4-thiadiazole derivatives; European Journal of Medicinal Chemistry $45 \quad$ (2010) 5200e5207
48. Serwar M., Akhtar T., Hameed S., Khan K.M;Synthesis, urease inhibition and antimicrobial activities of some chiral 5-aryl-4-(1-phenylpropyl)-2H-1,2,4triazole-3-(4H)-thiones; ARKIVOC., 2009, (vii), 210.

49. Khan M.H., Hameed S., Yasin K.A., Akhtar T., KhanK.M; Design, synthesis, and urease inhibition studies of a series of 4-amino-5-aryl-3H1,2,4-triazole-3-thiones; Monatsh Chem (2010) 141:479-484

50. Diwedi R., Alexandar S., Chandrasekar M.N.J; Rapid and efficient synthesis of microwave assisted some bis-1, 2, 4-triazole derivatives and their antioxidant and anti-inflammatory evaluation; RJPBCS, 2011, 2, 194.

51. Yuksek H., Kolaylı S., Kuçuk M., Yuksek M.O., Ocak U., Şahinbaş E., Sivrikaya E., Ocak M; Synthesis and antioxidant activities of some 4benzyl-idenamino-4,5-dihydro- $1 \mathrm{H}$ 1,2,4-triazol-5-one derivatives;Ind. J. Chem. Sect-B, 2006, 45B(3), 715.

52. Qin X., Yu H., Liu J., Dai H., Bing G., Qin Z., Zhang X., Wang T., Fang J; Synthesis and biological activity of novel N-(5-((1H-1,2,4-triazol-1yl)methyl)-4-tert-butylthiazol-2-yl)-4carboxamide derivatives; ARKIVOC., 2009, (ii), 201.

53. Liu J., Li L., Dai H., Liu Z., Fang J; Synthesis and biological activities of new 1H-1,2,4-triazole derivatives containing ferrocenyl moiety; Journal of Organometallic Chemistry 691 (2006) 2686-2690

54. Kane J.M., Baron B.M., Dudley M.W., Sorensen S.M., Staeger M.A., Miller F.P; 2,4-Dihydro-3H-1,2,4-triazol-3ones as anticonvulsant agents; J. Med. Chem. 1990, 33, 2772.

55. Liu X.Y., Xu W.F., Wu J.D; Synthesis of 4-Amino-5-furyl-2-yl-4H-1, 2, 4- 
triazole-3-thiol;Chinese Chemical Letters., 2003, 14(8), 790.

56. Sen S., Tiwari R; Synthesis of 2-ochlorophenyl-5-oxo-5,6 dihydro- $4 \mathrm{H}$ thiazolo [2,3-b] 1,3,4-triazole; Indian J Heterocyclic Chem. 1995; 5: 87.

57. Mohan J., Kataria S., Malik N;Synthesis and Anti diuretic activity of thiazolo [3,2-b]-s-triazoles; Indian $\mathrm{J}$ Heterocyclic Chem 1996; 6: 21.

58. Chande M.S., Jagtap R.S; Synthesis and biological activity of organophosphorus compounds;Indian J Chem 1997; 36B: 199.

59. Kudari S.M., Sangamesh B.E; Synthesis of 1,8-Bis (4-amino-5-mercapto-1,2,4triazol-3-yl) octanes and the derivatives;Indian J Heterocyclic Chem 1999; 9: 99.

60. Kim D.K., Kima J., Park H.J; Design, synthesis, and biological evaluation of novel 2-pyridinyl-[1,2,4]triazoles as inhibitors of transforming growth factor $\beta 1$ type 1 receptor;Bioorganic \& Medicinal Chemistry 12 (2004) 20132020

61. Akbarzadeh T., Tabatabai S.A., Khoshnoud M.J., Shafaghic B., Shafieea;Design and Synthesis of $4 \mathrm{H}-$ 3-(2-Phenoxy)phenyl-1,2,4-triazole Derivatives as Benzodiazepine Receptor Agonists;Bioorganic \& Medicinal Chemistry 11 (2003) 769773.
62. Balba M., Abd El-Hady N., Taha N., Rezki N., El Ashry H.A;Inhibition of a-glucosidase and a-amylase by diaryl derivatives of imidazole-thione and 1,2,4-triazole-thiol;European Journal of Medicinal Chemistry 46 (2011) $2596 \mathrm{e} 2601$

63. Siwek A., Wujec M., Dobosz M., Jagiełło-Wojtowicz E., Chodkowska A., Kleinrok A., Paneth P., Synthesis and pharmacological properties of3(2-methyl-furan-3-yl)-4-substituted$\Delta$ 2-1,2,4-triazoline-5-thiones; Eur. J. Chem. 6(1), 2008, 47-53

64. Siddiqui A.A., Mishra R., Shaharyar M., Husain A., Rashid M., Pal P; Triazole incorporated pyridazinones as a new class of antihypertensive agents: Design, synthesis and in vivo screening; Bioorganic \& Medicinal Chemistry Letters 21 (2011) 10231026

65. Ouyang X., Chen X., Piatnitski E.L., Kiselyov A.S., He H.Y;Synthesis and structure-activity relationships of 1,2,4-triazoles as a novel class of potent tubulin polymerization inhibitors;Bioorganic \& Medicinal Chemistry Letters 15 (2005) 51545159.

\section{How to cite this article:}

Anjali Thakur, Puspraj S. Gupta, Parjanya kumar shukla, Amita verma and Prateek Pathak. 2016. 1, 2, 4-Triazole Scafolds : Recent Advances and Pharmacological Applications Int.J.Curr.Res.Aca.Rev. 4(2): 277-296. doi: http://dx.doi.org/10.20546/ijcrar.2016.402.031 